\title{
腰椎椎間板ヘルニアに対する経皮的レーザー椎間板切除術
}

\author{
和仁会病院整形外科 \\ 前田公 \\ 同手術室 \\ 田代弘・溝 越 宏 昭 \\ 要野記念病院整形外科 \\ 高 木 謙司郎
}

\section{Percutaneous Laser Discectomy for Lumbar Disc Herniation}

\author{
by \\ Hiroshi Maeda \\ Department of Orthopaedic Surgery, \\ Wajinkai Hospital \\ Hiroshi Tashiro and Hiroaki Mizokoshi \\ Department of Operation, \\ Wajinkai Hospital \\ Kenshiro Takagi \\ Department of Orthopaedic Surgery, \\ Aino Memorial Hospital
}

\begin{abstract}
Percutaneous laser discectomy (PLD) is a safe, simple and minimally invasive procedure for lumbar disc herniation. Early therapeutic results were evaluated for 10 patients with lumbar disc herniation treated by PLD. The improvement rate of PLD according to JOA scroe was more than $75 \%$ in 3 patients, 74 to $50 \%$ in 5 and less than $49 \%$ in 2 at least 3 months after PLD, giving an overall success rate of $80 \%$. There was no significant difference in clinical data and total irradiated energy between successful ( 8 patients) and unsuccessful ( 2 patients) groups. However, the age of 3 patients who obtained excellent results was under 40 years old.
\end{abstract}

Key words : Intervertebral disc herniation (椎間板ヘルニア), Percutaneous discectomy (経皮的椎間板切除術), Laser (レーザー)

\section{はじめに}

1987 年, Choy ら ${ }^{1)}$ が椎間板ヘルニアに対して経皮 的レーザー椎間板切除術（以下，PLD）を行って以 来, 本法は安全かつ簡便な治療法として普及しつつあ る. しかし本法の歴史は浅く，その有効性についての 検討は十分とは言えない. 我々も 1995 年 8 月以来, ヘルニア患者に対してレーザーによる治療を行ってお り，その短期治療成績について検討したので報告する.

\section{対象および方法}

PLDを行った 25 例のヘルニア患者のうち, 術後 3 加 6 力月（平均 4.5 力月）経過し, 直接検診可能で あった 10 例を対象とした。年齢は 19〜78 歳, 平均 53 歳, 男性; 8 例, 女性; 2 例であった. 適応は腰痛 および下肢痛やしびれがあり, 保存的治療の効果が得 られない患者で, 後綐勒帯を穿破していないヘルニア を有するものとした. 手術前後の臨床所見を日整会腰 痛判定基準（JOA score）のうち自他覚所見（15 点） 


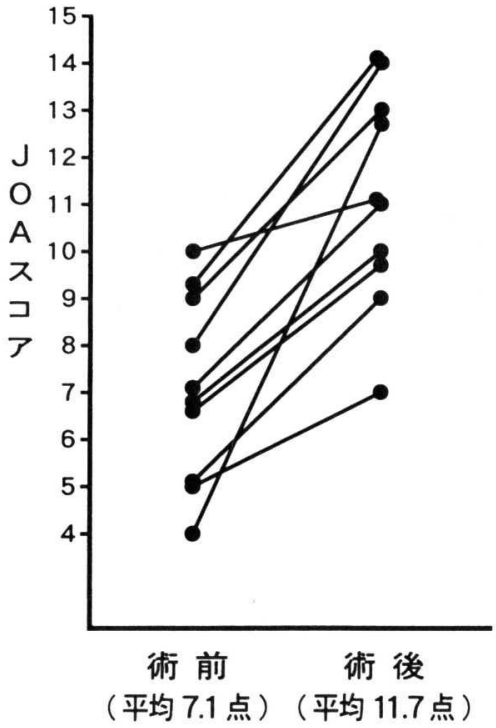

図 1 JOA score $の$ 術後変化

10 例中 8 例に $50 \%$ 以上の改善率が得られ，有 効率は $80 \%$ である。

により評価し, 平林法による改善率を求めた。MRI は術前 8 例, 術後 5 例で撮影できた。

\section{手 術手技}

患者を側臥位とし, 腰部正中線より $8 \sim 12 \mathrm{~cm}$ の部 位を穿刺部位とし, 局所麻酔後, 長さ $15 \mathrm{~cm}$, 径 $1.3 \mathrm{~mm}$ の注射針を X 線透視像を見ながら椎間板内に 挿入する.この中に $400 \mu$ のレーザーファイバーを挿 入し, Nd：YAG レーザーを 656〜2808J 照射した。

結

果

術前の JOA score は平均 7.1 点で, 術後は 11.7 点に改善した（図 1). 症状改善率は $75 \%$ 以上（優） が 3 例，74 50\%（良）が 5 例，50\% 未満（可）が 2 例で，有効率は $80 \%$ であった。 そこで有効例 8 例と 無効例 2 例について臨床像や照射量に差があるか否か を検討すると, 両群間に明らかな差は見られなかった. 但し, 有効例 8 例の内， $75 \%$ 以上の改善率が得られ た 3 例は，いずれも 40 歳以下であった。術前後に MRI を撮影できた 5 例のうち，ヘルニアの消失が見 られたのは 1 例のみであった。 1 例に一過性腰痛が見 られた以外, 合併症はなかった。

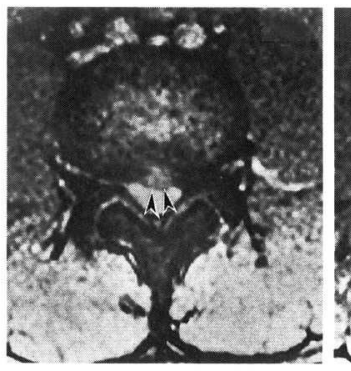

術前

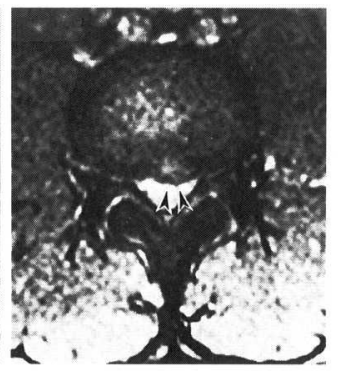

術後 6 个月
図 219 歳, 男性の腰椎 MRI 横断像 術前後でL4/5のへルニア (矢頭) の大きさに 変化はない。
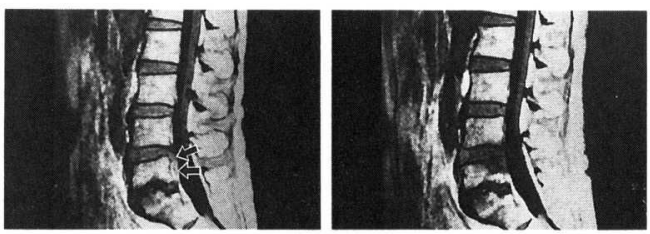

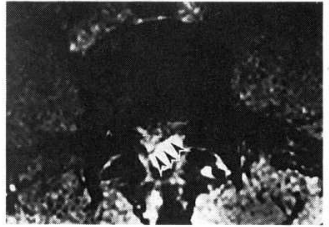

術前

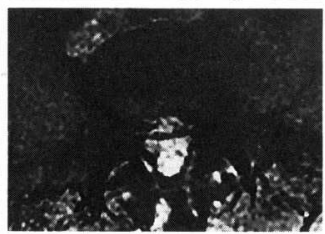

術後 3 个月
図 350 歳, 男性の腰椎 MRI 矢状断像と横断像 椎体後面にまで下垂した大きなへルニア（矢印, 矢頭）は術後には消失している.

症例

症例 1（図 2), 19 歳, 男性. 腰痛, 左下肢痛, ᄂ びれがあり, SLR 40 度, 軽度の知覚障害, 筋力低下 を示し, JOA scoreは 7 点であった。 MRIでは L4 $/ 5$ 椎間に突出型ヘルニアを認め, 1520Jのレーザー を照射した，術後 1 日より SLR 80 度，筋力はほぼ 正常となり, 1 週間後は 12 点, 6 力月後は 14 点と回 復し, 改善率は 86\% であったが, 6 カ月後の MRI で はヘルニアの縮小は殆ど見られなかった.

症例 2 (図 3), 50 歳, 男性. 強い下肢痛としびれ があり, SLR 45 度, 軽度の知覚障害と明らかな筋力 低下を示し, JOA scoreは 5 点であった. MRI で は L4/5 間に椎間板から椎体後面に下垂したヘルニア 
を認め，2808J のレーザーを照射した。直後より SLR は 80 度, 筋力低下も軽度となり, その後, 徐々 に回復し 3 カ月で 10 点, 6 カ月で 15 点満点となった. 3 カ月後の MRI でヘルニアはほとんど消失していた。

\section{考察}

本法は love 法手術のように直視下にヘルニアを摘 出するものではないので, 治療成績がやや低く，有効 率 59 ～ $81 \%$ と報告されている Kosaka ら² は全体の有効率を $59 \%$ としているが, これを突出型ヘルニアに限定すれば $73 \%$ になると述 べている. 我々の症例も 1 例を除き全て突出型ヘルニ アであり，10 例の有効率は $80 \%$ であった。ただし 1 例は比較的大きい後縦勒帯下ヘルニアと考えられたが, PLD 後 3 カ月でヘルニアはほほ完全に消失していた. 従って，椎間板高位外にある大きなへルニアでも，後 絴勒带を破らずヘルニア自体に椎間板の圧力が及んで いれば PLD の効果が期待できるものと思われた。

適応年齢について，西島ら ${ }^{4)} 40$ 歳未満に限定す れば有効率 $92 \%$ であると述べているが，我々の症例 でも 40 歳未満の 3 名はいずれも $75 \%$ 以上の改善率を 示し，有効率は $100 \%$ であった。一方， 40 歳以上で は改善率が 74 50 \%で有効率は $71 \%$ であった。そこ でPLDを行うにあたっては，ヘルニア形態，特に後 縦勒带穿破の有無を十分に検討することが最も重要で, また年齢も考慮する必要があると思われた。
本法の作用機序については，レーザーによる蒸散お よびその後の組織変化に伴う椎間板内圧の減少による と考えられている2 が，我々も同様の機序を考えてい る、ただし内圧の減少によりヘルニアの大きさが急速 に縮小するのでは無く, 椎間板内圧の減少がヘルニア の硬度を減少させ，ひいては神経根に対するへルニア の易刺激性が低下するために症状が急速に改善するも のと思われる，そこで症例 1 ではへルニアの術後の縮 小は無かったが，ヘルニアそのものが軟らかくなり， 神経根へかかる刺激が減少したため症状が改善したと 推測している.

結

語

腰椎椎間板ヘルニア 10 例に経皮的レーザー椎間板 切除術を行い, $80 \%$ の有効率を得た.

\section{参 考 文 献}

1) Choy, D.S.J. et al.: Percutaneous laser nucleolysis of lumbar disks. N Engl J Med., 317 : 771-772, 1987.

2) Kosaka, R. et al.: Percutaneous laser nucleomy for lumbar disc herniation. J Orthop Sci., 1 : 102-112, 1996.

3）宮坂芳郎ら：腰椎椎間板ヘルニアに対するレーザー䯣 核蒸散法の経験。日脊外会誌, $6: 327,1995$.

4）西島雄一郎ら：鏡視下経皮的レーザー椎間板切除術。 日脊外会誌, $6: 83-90,1995$ 